\title{
Media Viewboard Sebagai Klasifikasi Jumlah Surat Keputusan Online Pada Perguruan Tinggi
}

\author{
Untung Rahardja ${ }^{1}$ \\ Eka Purnama Harahap ${ }^{2}$ \\ Ayu Suciani ${ }^{3}$ \\ Dosen STMIK Raharja $^{1,2}$, Mahasiswa STMIK Raharja ${ }^{3}$
E-mail: untung@raharja.info ${ }^{1}$, ekapurnamaharahap@ raharja.info $^{2}$, ayu.suciani@raharja.info ${ }^{3}$

\begin{abstract}
ABSTRAK
Mencari informasi melalui internet merupakan salah satu bentuk kegiatan yang sudah menjamur di masyarakat indonesia maupun global, tidak bisa dipungkiri lagi saat ini internet hampir sudah menjadi kebutuhan pokok bagi masyarakat. Namun, saat ini penyebaran informasi masih konvesional dan kurang diolah dengan baik sehingga tidak uptodate. Banyaknya surat keputusan yang berada pada suatu Organisasi atau Institusi Perguuan Tinggi merupakan hal wajar akan tetapi akan menjadi sebuah masalah bila tidak adanya suatu cara pengolahan yang baik. Maka daripada itu pada penelitian ini akan membahas perihal media informasi surat keputusan online dengan media viewboard pada website surat keputusan Perguruan Tinggi Raharja. Dengan adanya media viewboard pada website surat keputusan Perguruan Tinggi Raharja dapat memberikan kemudahan bagi pengunjung dalam mendapatkan informasi klasifikasi jumlah dari surat keputusan lebih cepat. Manfaat dari media viewboard dapat mempermudah pengunjung dalam mengakses informasi klasifikasi jumlah dari surat keputusan yang ada di Perguruan Tinggi Raharja yang terupdate.
\end{abstract}

Kata Kunci : Viewboard, Informasi, Pengunjung, Surat Keputusan

\begin{abstract}
Search for information through internet liquid one form of activity that s mushroomed and global community, it cannot be denied again today the internet's virtually sbecome a basic requirement for the community. However, currently still accounting for the dissemination of information and less processed with either so it's not uptodate. The number of letter decision while at an organization or Institution High liquidPerguuan it reasonable however will be discussing the problem when the absence of a way of processing. Then than it did on this research will address the subject of media information online with the media Decree viewboard on the website of the College decision letter Raharja. With the presence of media viewboard on the website of the College decision letter Raharja can provide convenience for visitors in getting information classification number from the letter of decision more quickly. The benefits of viewboard media can facilitate visitors in and access the information classification number from the existing Decree in College Raharja client.
\end{abstract}

Keywords : Viewboard, Website, Information, Visitor, Decree 


\section{PENDAHULUAN}

Perguruan Tinggi Raharja merupakan sebuah Perguruan Tinggi Swasta unggulan di Tangerang, Banten dengan konsentrasi pengajaran manajemen dan ilmu komputer. Semboyannya adalah "Get the Better Future by Computer Science" yang bergerak di bidang Teknologi Informatika. Kebutuhan akan informasi yang efektif, efisien, cepat, dan akurat sangatlah dibutuhkan bagi civitas Perguruan Tinggi Raharja. Dengan terus adanya kemajuan teknologi, Perguruan Tinggi Raharja dituntut untuk terus berinovasi dalam menghadapi perkembangannya.

Saat ini internet merupakan suatu hal yang sangat penting sebagai pendukung dalam kelancaran mencari informasi. Upaya peningkatan daya saing Perguruan Tinggi melalui internet adalah dengan cara membangun website dan dengan semakin canggihnya teknologi membuat beberapa Perguruan Tinggi berlomba-lomba untuk membangun sebuah website sistem informasi.

Menurut Hakim Lukmanul dalam bukunya yang berjudul "Cara Cerdas Menguasai Layout, Desain, dan Aplikasi" [2004], Website merupakan fasilitas internet yang menghubungkan dokumen dalam lingkup lokal maupun jarak jauh. Dokumen pada website disebut dengan web page dan link dalam website memungkinkan pengguna bisa berpindah dari satu page ke page lain (hyper text), baik diantara page yang disimpan dalam server yang sama maupun server diseluruh dunia. Pages diakses dan dibaca melalui browser seperti Netscape Navigator atau Internet Exploler berbagai aplikasi browser lainnya [1]. Website surat keputusan juga merupakan merupakan hal yang terpenting bagi dunia pendidikan. Dengan adanya website surat keputusan tersebut kita dapat mengetahui informasi-informasi yang detail dan terupdate perihal surat keputusan yang baru dikeluarkan oleh pimpinan perguruan tinggi. Salah satu website surat keputusan yang ada pada Perguruan Tinggi Raharja yaitu skptr.ilearning.me. Sebagai salah satu media informasi secara online pada Perguruan Tinggi Raharja, diharapkan skptr,ilearning.me dapat terus berkembang dalam memberikan informasi yang uptodate perihal seluruh surat keputusan yang baru dikeluarkan.

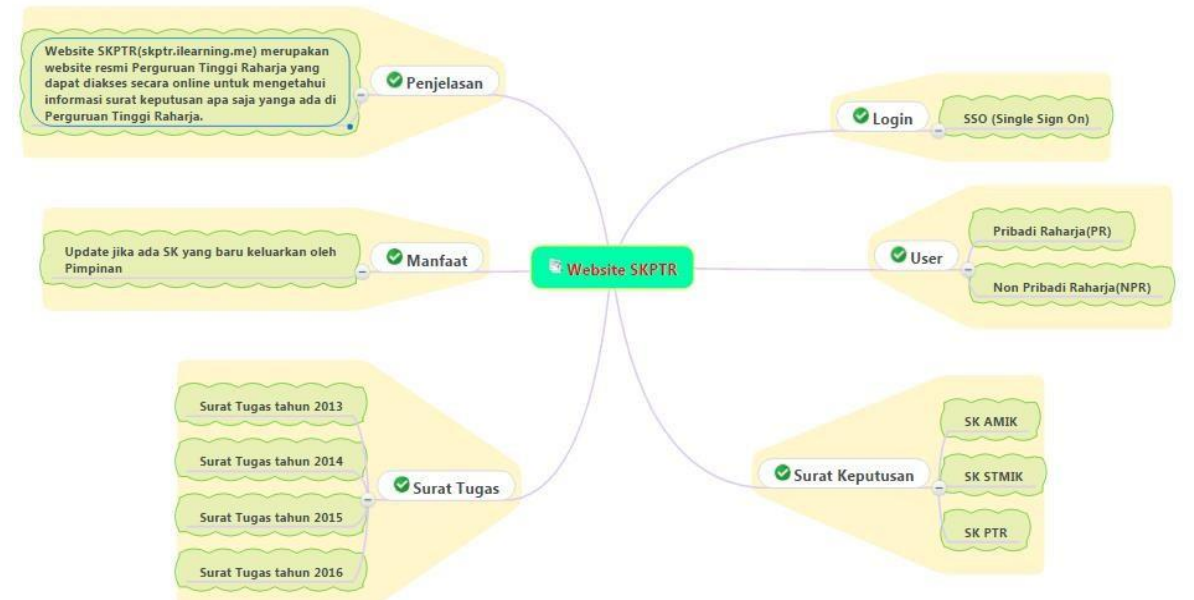

Gambar 1. Mind Mapping website SKPTR

70| Untung, Eka, Ayu-Media Viewboard Sebagai Klasifikasi Jumlah.... 
Gambar diatas menjelaskan mind mapping dari website SKPTR yang terdiri dari : (1) Login yaitu menggunakan SSO ( Single Sign On) yaitu Rinfo, (2) User yaitu Pribadi Raharja(PR) dan Non Pribadi Raharja (NPR), (3) Surat Keputusan yaitu ada SK AMIK, SK STMIK, dan SK PTR, (4) Surat Tugas yaitu ada Surat Tugas tahun 2013, Surat Tugas tahun 2014, Surat Tugas tahun 2015, dan Surat Tugas tahun 2016, (5) Manfaat : Update jika ada SK yang baru keluarkan oleh Pimpinan, (6) Penjelasan yaitu website SKPTR merupakan website SKPTR (skptr.ilearning.me) merupakan website Perguruan Tinggi Raharja yang dapat diakses secara online untuk mengetahui informasi surat keputusan apa saja yang ada di Perguruan Tinggi Raharja.

\section{METODE PENELITIAN}

\subsection{Literature review}

Penelitian yang sudah dilakukan sebelumnya mengenai survey secara online dan penelitian lain yang berkaitan. Dalam mengembangkan dan upaya menyempurnakan sistem e-journal ini maka diperlukan melakukan studi pustaka (literature review) sebagai salah satu dari penerapan metode penelitian yang akan dilakukan. Terdapat 10 (Sepuluh) point diantaranya yaitu:

1. Penelitian yang dilakukan oleh Königsberger, Jan., dan Mitschang, Bernhard (2016) yang berjudul "A Semantically-Enabled SOA Governance Repository (Application Paper)”. Penelitian ini membahas tentang perusahaan sering berjuang untuk menangani kompleksitas dan kegiatan pemerintahan diperlukan setelah pergeseran paradigma ini. Karena itu kami hadir repositori semantik-enabled SOA pemerintahan sebagai pusat alat untuk mengelola dan mengatur semua kegiatan yang berhubungan dengan SOA dalam perusahaan. Repositori ini didasarkan pada aspek-aspek kunci sebelumnya didefinisikan pemerintahan kami serta kami SOA tata kelola Meta Model (SOA-GovMM). Kami menjelaskan bagaimana kami repositori mampu mendukung dan meningkatkan kecepatan dan proses fleksibilitas dari perusahaan IT. [2].

2. Penelitian yang dilakukan oleh Fauzan Masykur dan Ibnu Makruf Pandu Atmaja (2015) yang berjudul "Sistem Administrasi Pengelolaan Arsip Surat Masuk Dan Surat Keluar Berbasis Web". Pengelolaan arsip surat masuk dan surat keluar selama ini masih dilakukan secara konvensional berupa hard copy atau lembaran-lembaran kertas yang menyulitkan dalam hal pencarian jika sewaktu-waktu dibutuhkan. Kesulitan dan kerumitan tersebut dapat diatasi dengan memanfaatkan kemajuan teknologi informasi yakni memanfaatkan bahasa pemrograman PHP dan 
database MySql untuk mengelola arsip surat keluar dan surat masuk. Pengelolaan memanfaatkan bahasa pemrograman PHP dan database MySql tersebut tidak lagi berupa hardcopy atau lembaran kertas namun sudah berupa file hasil dari pemindai atau scan dari surat yang asli. [3].

3. Penelitian yang dilakukan oleh Apriansyah Putra (2015) yang berjudul "Sistem Pengarsipan Elektronik Dokumen Mutu Universitas Sriwijaya" Penerapan sistem pengarsipan secara elektronik dalam sebuah organisasi diperlukan untuk mendukung kegiatan pengarsipan dalam upaya tercapainya efektifitas dan efisiensi dalam pengelolaan serta mampu melestarikan arsip yang memiliki informasi atau nilai penting bagi penggunanya. [4].

4. Penelitian yang dilakukan oleh Maxsi Ary. pada tahun 2015 dengan judul "Pengklasifikasian Karakteristik Mahasiswa Baru Dalam Memilih Program Studi Menggunakan Analisis Cluster”. Pengelompokan Objek (object clustering) adalah salah satu proses dari objek mining yang bertujuan untuk mempartisi objek yang ada kedalam satu atau lebih cluster objek berdasarkan karakteristiknya. Perguruan tinggi swasta merupakan salah satu perguruan tinggi alternatif bagi masyarakat untuk menghadapi peningkatan permintaan terhadap kebutuhan pendidikan. Jumlah perguruan tinggi swasta khususnya di Bandung dan umumnya di Indonesia berjumlah cukup banyak. Jumlah perguruan tinggi dan cara yang digunakan perguruan tinggi untuk menarik minat calon mahasiswa menjadi hal yang menarik untuk dikaji. Sebagai alasan ketatnya persaingan dalam mencari calon mahasiswa baru, tidak dipungkiri terdapat beberapa cara yang dilakukan yang sebetulnya tidak perlu dilakukan. Persoalan yang dikemukakan yaitu mengklasifikasikan karakteristik mahasiawa baru dalam memilih program studi menggunakan analisis cluster. [5].

5. Penelitian yang dilakukan oleh Jayadi pada tahun 2012 dengan judul "ANALISIS NILAI EFISIENSI MOTOR INDUKSI DENGAN DIAGRAM LINGKARAN”. Untuk mengetahui nilai efisiensi dimaksud dapat dilakukan analisis berdasarkan data teknik dan data hasil pengujian. Dalam penelitian ini dilakukan analisis nilai efisiensi dengan menggunakan diagram lingkaran yang didasarkan hasil pengujian beban nol dan hubung singkat. Pengujian beban nol dan hubung singkat akan menentukan garis daya keluaran dan titik pusat diagram lingkarannya. Analisis efisiensi dilakukan pada berbagai kondisi kerja motor dengan menentukan daya keluaran dan masukan melalui diagram lingkaran [6].

6. Penelitian yang dilakukan oleh Sri Hartati pada tahun 2015 dengan judul "RANCANG BANGUN SISTEM INFORMASI PENGARSIPAN SURAT KEPEGAWAIAN AMIK AKMI BATURAJA". Di Kepegawaian AMIK 
AKMI Baturaja proses pencatatan dan pengarsipan Surat masuk dan surat keluarnya masih dilakukan dengan cara manual menggunakan buku agenda yang dapat mempersulit pencarian data surat masuk dan surat, dan sering terjadinya surat yang hilang atau rusak. Solusi yang diusulkan untuk menyelesaikan masalah yang ada saat ini adalah dibangun suatu Sistem Pengarsipan Surat untuk memberikan kemudahan di Kepegawaian AMIK AKMI Baturaja [7].

7. Penelitian yang dilakukan oleh Defi Anggraeni dan Siska Iriani pada tahun 2013 dengan judul "Sistem Informasi Pengarsipan Surat Masuk Dan Surat Keluar Pada Kantor Kecamatan Pringkuku“. Pada kantor Kecamatan Pringkuku sistem pengarsipan surat masih menggunakan metode konvensional seperti masih menggunakan media kertas sebagai arsip utama, yang sering kali kita kesulitan mencari berkas karena mencari data satu persatu sehingga memerlukan waktu yang cukup lama untuk mencari arsip, bahkan seringkali arsip itu tidak di temukan karena banyaknya arsip yang ada selama bertahun - tahun lamanya. Tujuan dalam penelitian ini adalah menghasilkan sistem informasi pengarsipan surat masuk dan surat keluar pada Kantor Kecamatan Pringkuku. Untuk metode penelitian yang digunakan yaitu : Pengumpulan data, analisis sistem, perancangan sistem dan implementasi sistem. Hasil dari penelitian ini diharapkan dapat mempermudah sistem kearsipan yang berjalan di sana dan meminimalisasi kesulitan pencarian berkas. [8].

\section{HASIL DAN PEMBAHASAN}

Untuk mengatasi berbagai masalah diatas, maka diperlukan media yang mendukung proses yang cepat dan efisien dalam mengakses seluruh informasi. Ada beberapa macam media yang digunakan dalam penyebaran informasi. Salah satu contohnya yaitu Google Sheets. Google Sheets adalah aplikasi layanan pengolah dokumen, terutama untuk dokumen keuangan atau tabel yang terlihat sederhana, dengan menggunakan google sheets maka dapat membuat jumlah dari SK AMIK, SK STMIK, ataupun SK PTR lalu dihubungkan dengan diagram lingkaran (pie chart).

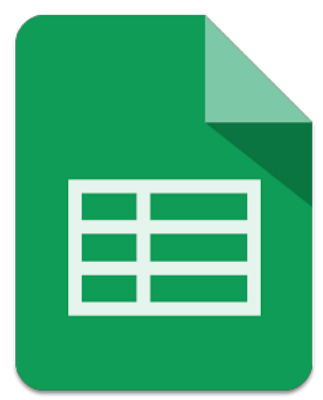

Gambar 2. Logo Google Sheets 
Dalam permasalahan penelitian kali ini, pemecahan masalahnya yaitu dengan menerapkannya media viewboard. Dikutip dari Technology Partners [9]. ViewBoard is a custom application created by Technology Partners, with it you can have the most important information you need to make mission critical business decisions on a daily basis in one easy to read dashboard. From metrics and socials to department level critical information, you decide what you want to have in your custom dashboard. The dashboard interface is fully dynamic, you are able to connect it to a CMS system or have it directly access your database to manage the information feeds. Di dalam google sheets terdapat berbagai macam diagram namun pada website SKPTR menggunakan diagram lingkaran (pie chart) untuk media viewboardnya agar lebih memudahkan untuk melihat jumlah SK AMIK, SK STMIK, ataupun SK PTR bagi pengunjung website SKPTR.

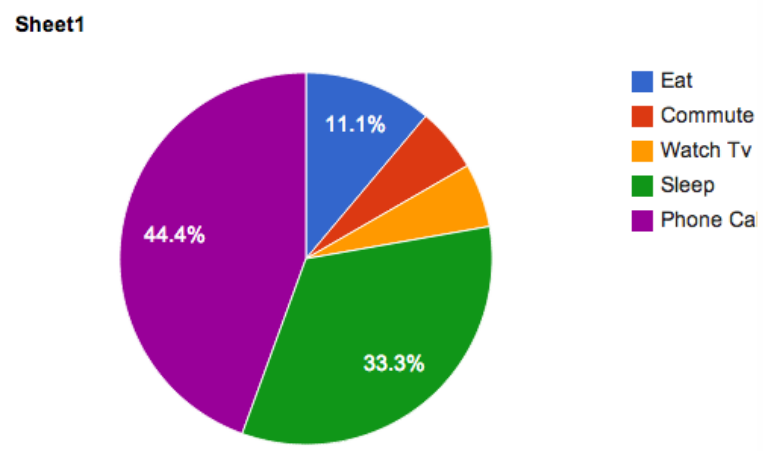

Gambar 3. Contoh diagram lingkaran (pie chart)

Berikut Langkah-langkah yang digunakan dalam penyelesaian penelitian :

a. Langkah pertama yaitu login google.

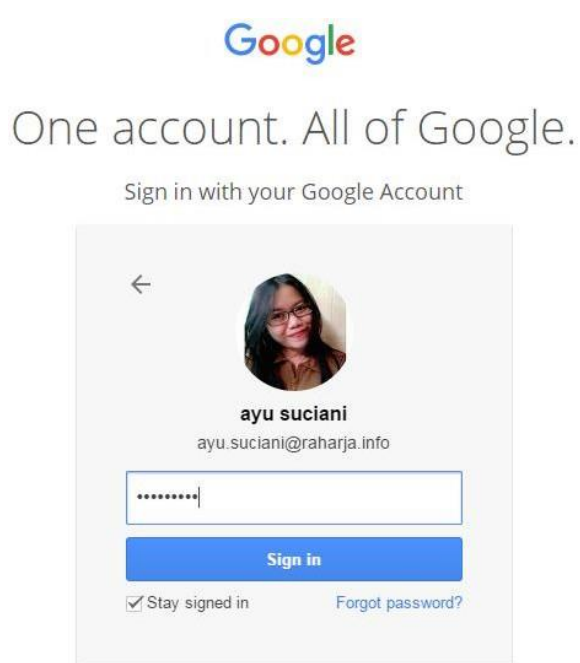

Gambar 4. Login akun Google

(Sumber: https://accounts.google.com/Login)

74| Untung, Eka, Ayu - Media Viewboard Sebagai Klasifikasi Jumlah.... 
Setelah berhasil login, lalu ke menu google diatas pojok kanan pilih Sheets.

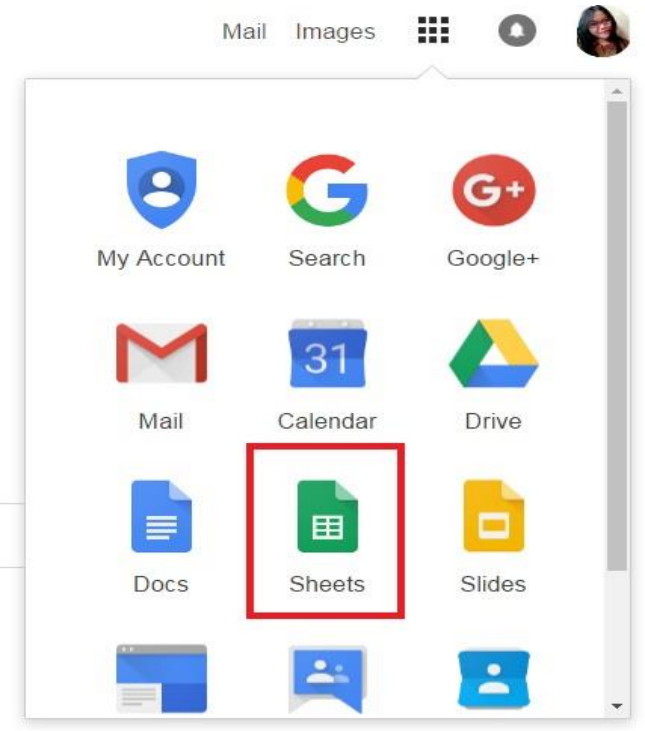

Gambar 5. Pilih Sheets

(Sumber: https://myaccount.google.com)

Setelah masuk ke dalam Sheets lalu tulis judul dokumen, isi jumlah semua masingmasing surat keputusan (SK) dan total keseluhan surat keputusan (SK).

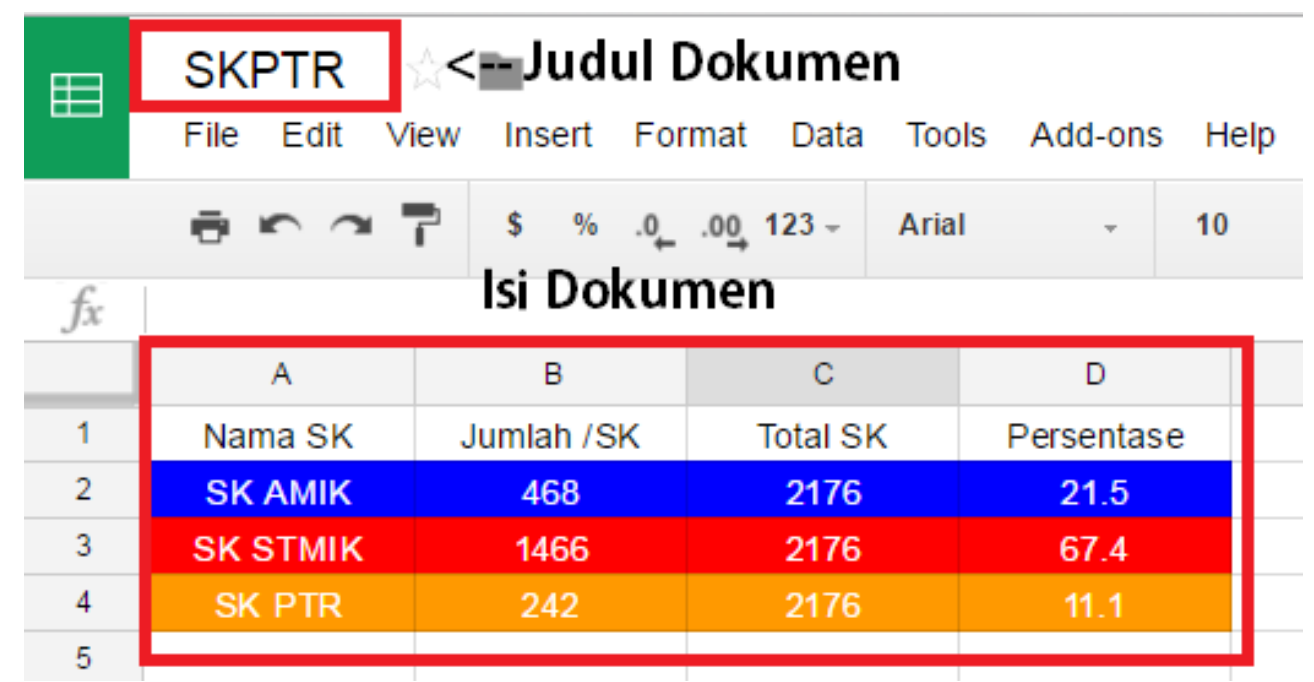

Gambar 6. Tulis Judul dan Isi Dokumen

(Sumber: https://docs.google.com/spreadsheets/) diagram.

Lalu blok semua isi dokumen pilih tools Insert - Chart-ecommendations 


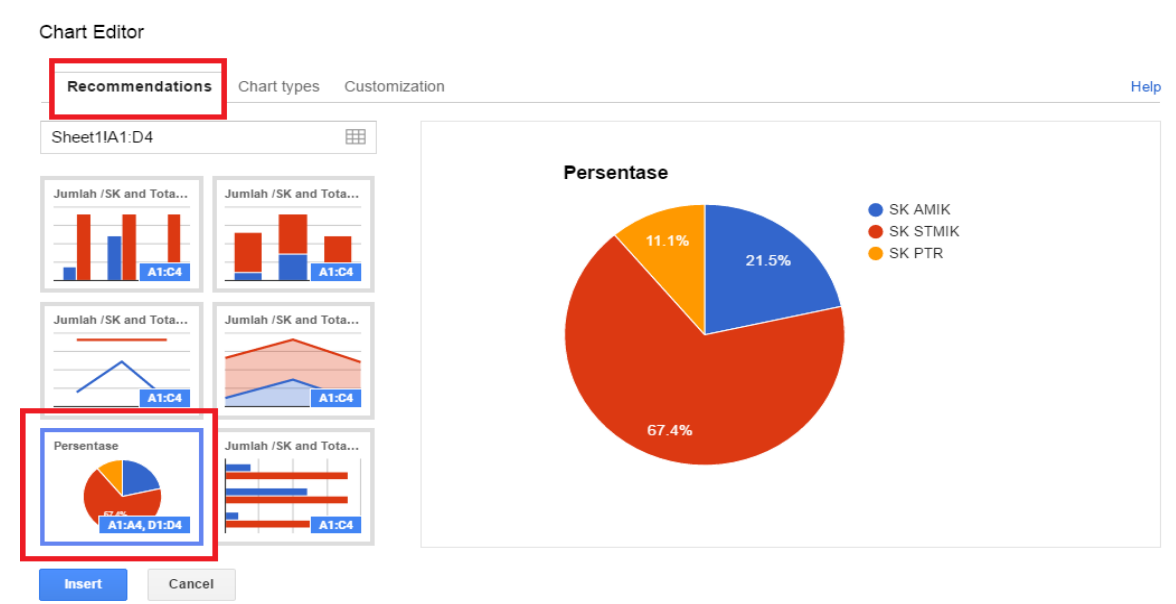

Gambar 7. Pilih bentuk diagram lingkaran

(Sumber: https://docs.google.com/spreadsheets/)

Setelah itu klik Customization untuk mengubah judul diagram atau mengedit diagram sesuai keinginan dan klik Insert.

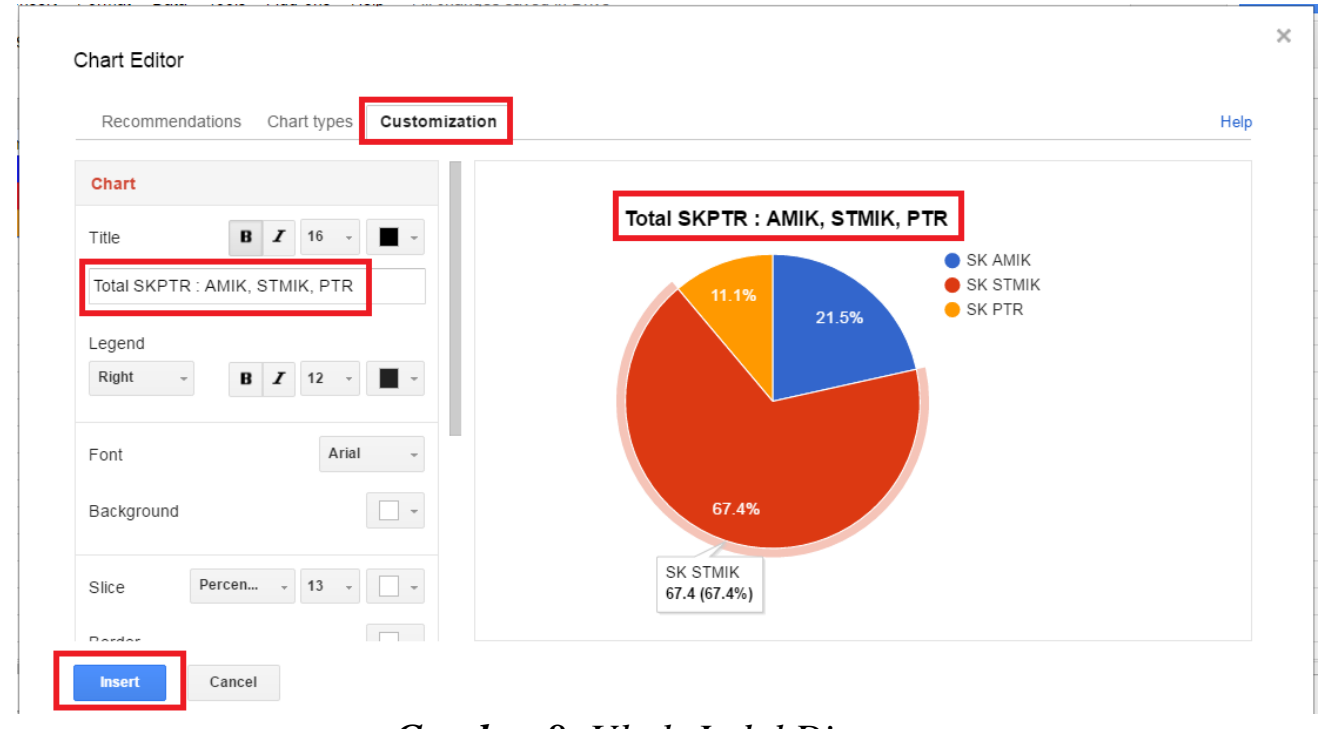

Gambar 8. Ubah Judul Diagram

(Sumber: https://docs.google.com/spreadsheets/)

Setelah diagram muncul akan klik segitiga kecil dipojok kanan kotak diagram dan klik Publish Chart. 


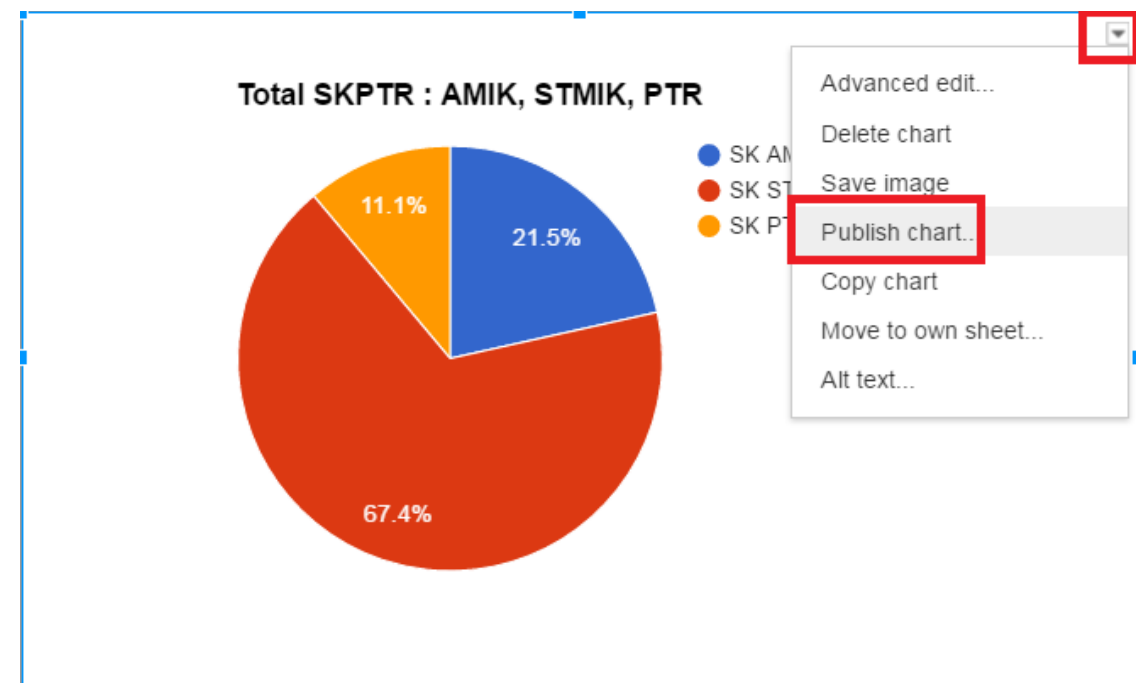

Gambar 9. Publish Chart

(Sumber: https://docs.google.com/spreadsheets/)

Dan lanjut klik Embed, copy kodingan embednya dan paste pada Homepage SKPTR

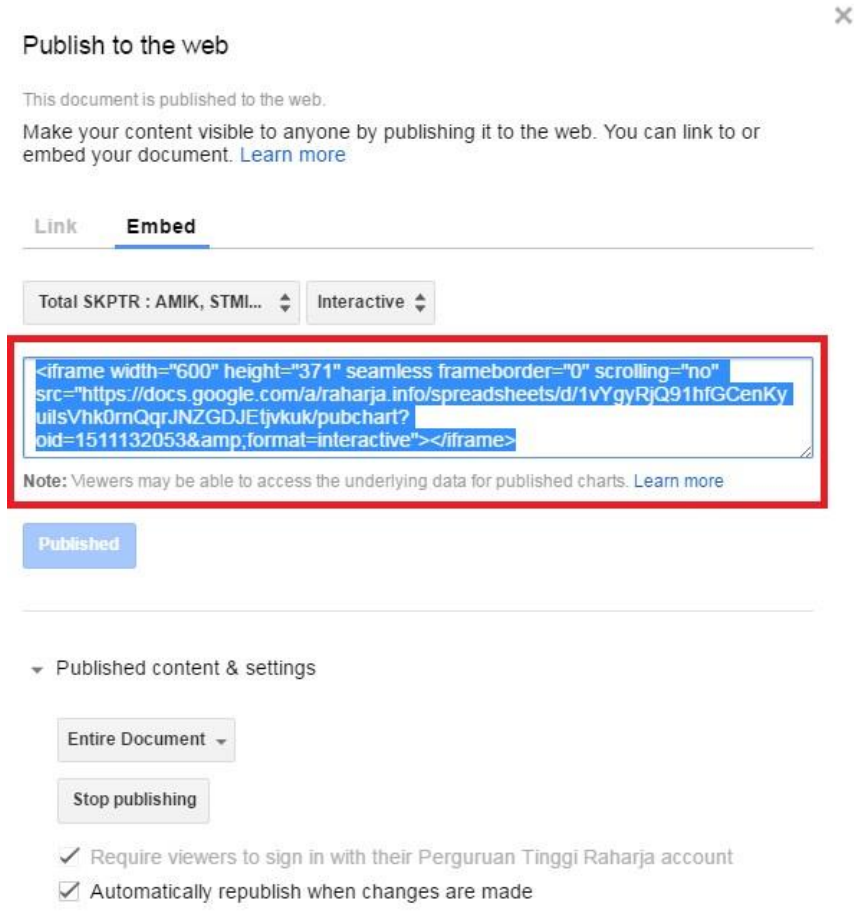

Gambar 10. Copy kodingan embed

(Sumber: https://docs.google.com/spreadsheets/) 


\subsection{Implementasi Program}

Viewboard dengan diagram lingkaran telah dibuat dan akan diimplementasikan sebagai media informasi surat keputusan online yang mudah untuk digunakan dan dimengerti oleh pengunjung website SKPTR. Berikut merupakan cara mengimplementasikan media viewboard pada website SKPTR: Langkah awal yaitu dengan Login ke iMe (iLearning Media) menggunakan SSO (Single Sign On) yaitu menggunakan Magic Key (Rinfo)

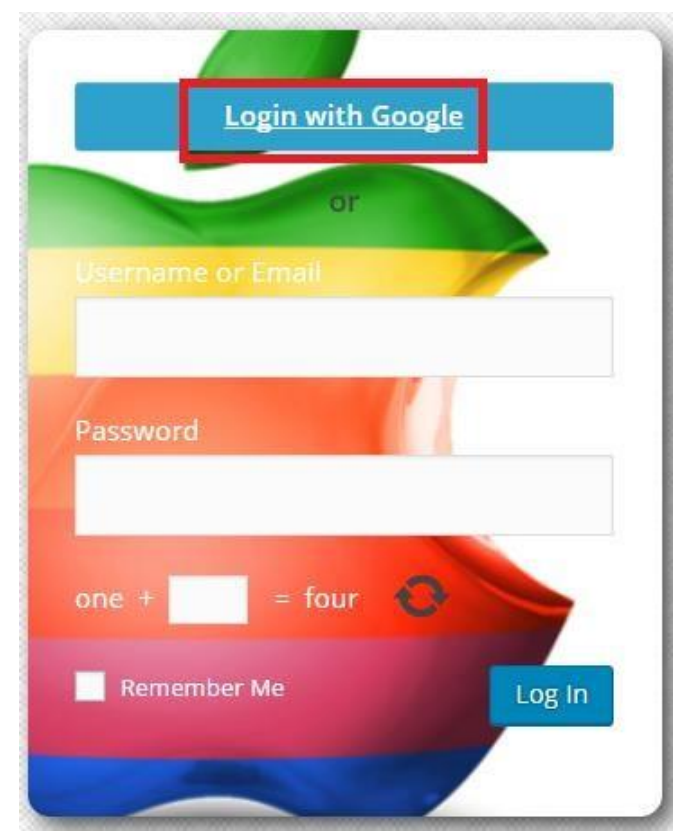

Gambar 12. Login iMe

(Sumber: http://ilearning.me/)

Setelah berhasil login, maka akan masuk ke dalam Dashboard lalu pilih site SKPTR, selanjutnya klik Visit Site.

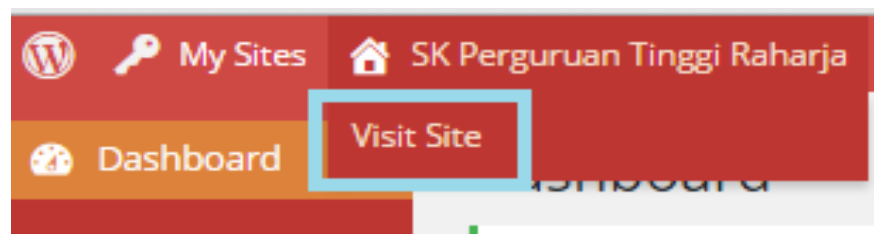

Gambar 13. Visit Site

(Sumber: http://skptr.ilearning.me/)

Akan muncul halaman homepage website SKPTR lalu klik Edit Page 


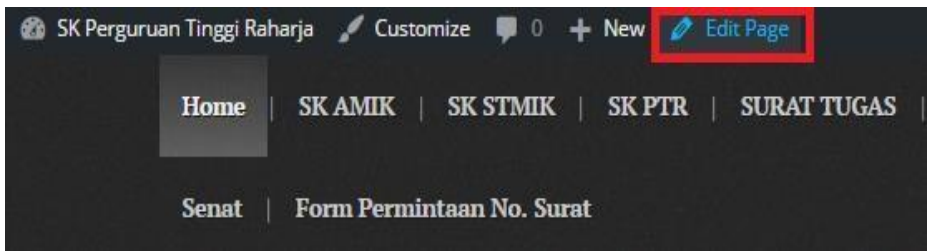

Gambar 14. Pilih Edit Page

(Sumber: http://skptr.ilearning.me/)

Lalu setelah itu Paste kodingan embed diagram tadi ke kotak Edit Page dan klik Update.

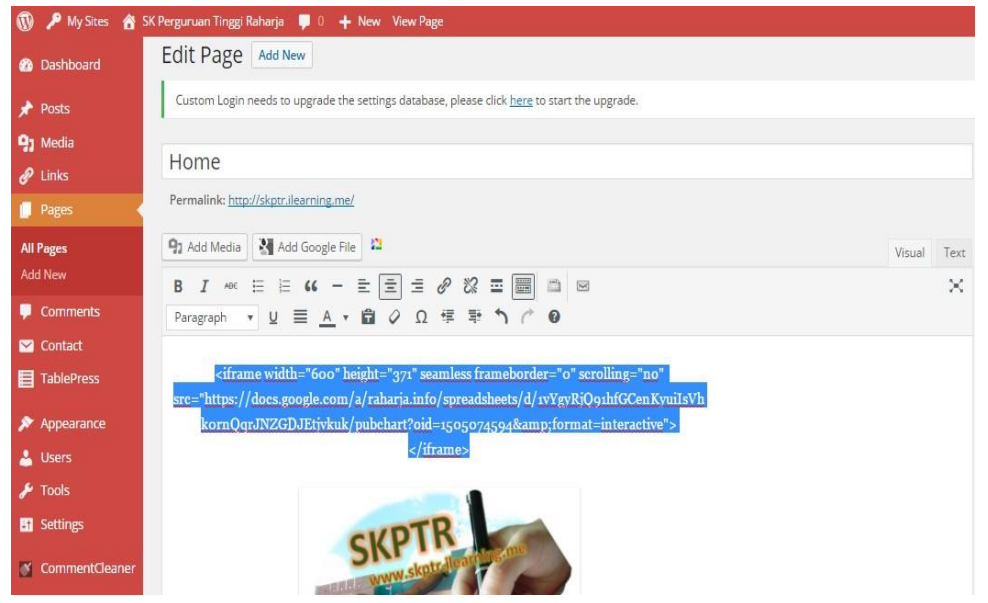

Gambar 15. Paste kodingan embed diagram

(Sumber: http://skptr.ilearning.me/)

Maka diagram lingkaran berhasil dipasang. Dan akan muncul pada tampilan homepage website SKPTR.

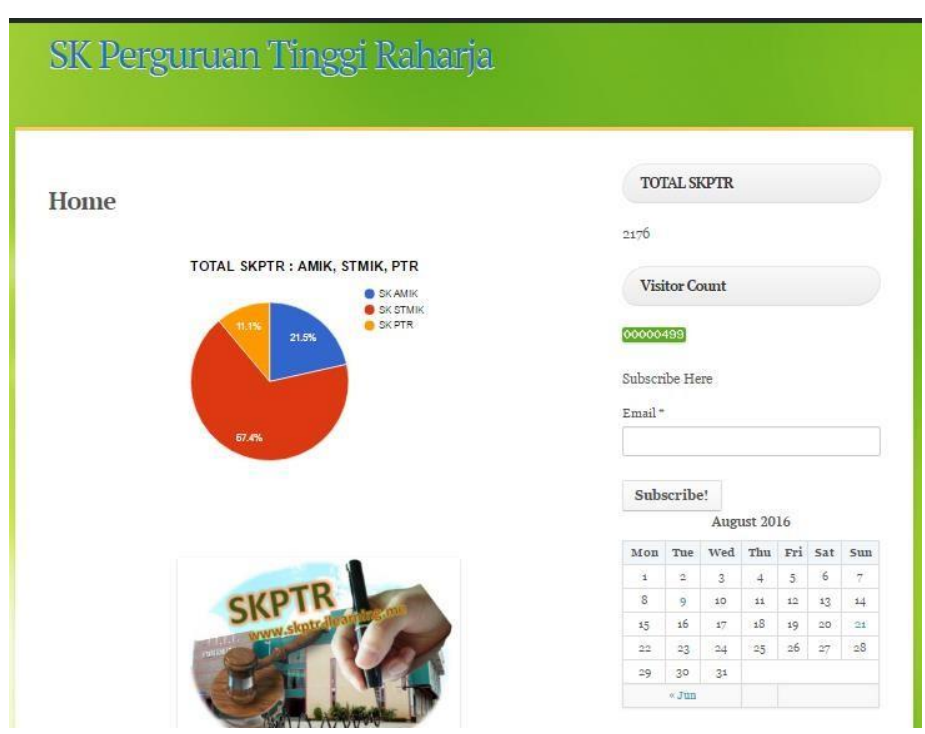

Gambar 16. Tampilan homepage website SKPTR

(Sumber: http://skptr.ilearning.me/)

79| Untung, Eka, Ayu - Media Viewboard Sebagai Klasifikasi Jumlah.... 


\section{KESIMPULAN}

1. Viewboard yang menggunakan diagram lingkaran (pie chart) merupakan media pendukung yang tepat untuk memberikan informasi jumlah surat keputusan pada website SKPTR. Hal ini dibuktikan dengan permasalahan yang terjadi serta dengan pemecahan masalah yang telah dijabarkan bahwa dengan adanya diagram lingkaran.

2. Pengunjung jadi lebih mudah mendapatkan informasi jumlah dari SK AMIK, SK STMIK, ataupun SK PTR dan hanya dengan mengklik bagian-bagian dari SK pada diagram maka pengunjung langsung dapat melihat jumlahnya.

3. Dan dengan adanya viewboard dapat mempermudah pengunjung dalam mengakses informasi surat keputusan terbaru dan tidak akan membuat pengunjung kesusahan jika ingin melihat jumlah masing-masing surat keputusan (SK).

\section{SARAN}

Penelitian yang baik adalah penelitian yang tidak hanya memberikan kesimpulan atas sebuah sistem. Namun juga dilengkapi dengan saran yang dapat membangun proses pengembangan sistem kedepannya. Berikut adalah 3 (tiga) saran terhadap penelitian:

1. Diharapkan sistem ini dapat dikembangkan kembali oleh penerus yang lainnya demi menyempurnakan Official Site SKPTR dengan adanya pengontrolan sistem, pengontentikasi pengguna hak akses terhadap sistem, adanya backup data dan lebih meningkatkan keamanan data terutama data-data yang bersifat confidential.

2. Adanya penghitungan jumlah pengunjung di dalam setiap kategori SK. Perhitungan ini mencakup seluruh pengunjung di dalam setiap SK yang sudah dimuat..

3. Diharapkan dengan hadirnya Official Site SKPTR ini dapat menjawab kebutuhan civitas kampus atau pengunjung demi mendapatkan informasi yang up to date seputar SK.

\section{DAFTAR PUSTAKA}

[1] Lukmanul, Hakim., 2004, Cara Cerdas Menguasai Layout, Desain, dan Aplikasi.

[2] Königsberger, Jan., dan Mitschang, Bernhard, 2016, A Semantically-Enabled SOA Governance Repository (Application Paper), Information Reuse and Integration (IRI), 2016 IEEE 17th International Conference on. IEEE. 
[3] Masykur, Fauzan dan Ibnu Makruf Pandu Atmaja, 2015, Sistem Administrasi Pengelolaan Arsip Surat Masuk Dan Surat Keluar Berbasis Web, IJNS-Indonesian Journal on Networking and Security 4.3.

[4] Apriansyah, Putra, 2015, Sistem Pengarsipan Elektronik Dokumen Mutu Universitas Sriwijaya, Jurnal Generic.

[5] Ary, Maxsi, 2016, PENGKLASIFIKASIAN KARAKTERISTIK MAHASISWA BARU DALAM MEMILIH PROGRAM STUDI MENGGUNAKAN ANALISIS CLUSTER, INFORMATIKA 2.1.

[6] Jayadi, 2012, ANALISIS NILAI EFISIENSI MOTOR INDUKSI DENGAN DIAGRAM LINGKARAN. Jurnal Ilmiah Mustek Anim Ha. Vol.1 No.1.

[7] Hartati, Hartati, 2015, RANCANG BANGUN SISTEM INFORMASI PENGARSIPAN SURAT KEPEGAWAIAN AMIK AKMI BATURAJA.

[8] Anggraeni, Defi, dan Siska Iriani, 2013, Sistem Informasi Pengarsipan Surat Masuk Dan Surat Keluar Pada Kantor Kecamatan Pringkuku, IJNS-Indonesian Journal on Networking and Security 4.3.

[9] Internet. (2014). Complete Organization In One Mobile Dashboard. 